\title{
Performance Of South African Automotive Exports Under The African Growth And Opportunity Act From 2001 To 2015
}

Norman Lamprecht, National Association of Automobile Manufacturers of South Africa, South Africa Aletta Sophia Tolmay, University of South Africa, South Africa

\begin{abstract}
The South African automotive industry is faced with the challenge of how to expand through exports in a saturated global automotive market, characterized by overcapacity. The vision of the South African automotive industry is to double its vehicle production to one million units per annum by 2020. However, domestic market limitations impede the ability to achieve sufficient economies of scale. Trade arrangements contribute towards increasing market access. The impact of the AGOA on automotive trade between the United States of America and South Africa was analyzed. It was found that the AGOA resulted in a substantial increase in two-way trade. Further research is encouraged with regard to the potential of regional integration in Africa for automotive exports from South African and the USA.
\end{abstract}

Keywords: African Growth and Opportunity Act; South African Automotive Industry; Automotive Exports

\section{INTRODUCTION}

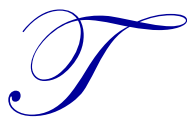
he automotive industry is frequently thought of as the most global industry. The products and stakeholders of the automotive industry are spread globally; however, a small number of companies dominate the industry (Lamprecht, 2009:132). Not surprisingly, the automotive industry is one of the largest contributors to the global economy as well as to the South African economy (Bronkhorst, Steyn \& Stiglingh, 2013:1282).

It is stated that a successful automotive industry is indicative of advanced economic success, and the South African automotive industry has become the country's leading manufacturing sector (AIEC, 2016:18). The domestic automotive industry is represented by an integrated tiered value chain and contributed $7.5 \%$ to the country's gross domestic product (GDP) in 2015 (AIEC, 2016:18). The vehicle manufacturing industry, along with the automotive component manufacturing industry, accounted for $33.5 \%$ of the country's total manufacturing output in 2015 , while record automotive export earnings of R151,5 billion ${ }^{1}$, up substantially by $30.9 \%$ from the R115,7 billion in 2014 comprised a significant $14.6 \%$ of South Africa's total export earnings (AIEC, 2016:7).

Although the automotive industry is a major role player in South Africa, it is still regarded as relatively small in the global automotive arena with a market share of global vehicle production of $0.68 \%$ in 2015 (AIEC, 2016:5).

Globalization brought about an abundance of opportunities, but also paved the way with various challenges for all industries, including the automotive industry. Within this global arena, the South African automotive industry is faced with the reality that global overcapacity results in a saturated market. Overcapacity means that the production volume exceeds demand from the market regarding products being manufactured. Since the South African automotive sector is export-market oriented, ongoing efforts to expand the industry's export business are imperative,

${ }^{1}$ The annual currency conversion (South African rand to US\$1) according to the South African Reserve Bank (www.resbank.co.za): 2015 (R12,75 to 1US\$).

Copyright by author(s); $\underline{\mathrm{CC}-\mathrm{BY}}$ 
especially in view of the vision to double vehicle production to one million vehicles per annum by 2020 (AIEC, 2016:19).

Added to the aforementioned, the South African automotive industry continues to be challenged by various obstacles such as intense competition in the global arena, which has substantially intensified through the global recession since 2008 (Komarasamy \& Hoque, 2015:975). The South African automotive industry is faced with fierce global competition from other developing countries (Naude, 2013:408; Komarasamy \& Hoque, 2015:996). The global competitiveness challenge is unlikely to diminish and the South Africa automotive industry is threatened by this challenge in the future (Lamprecht, 2009:10). There is a general consensus from all stakeholders that no efforts should be spared in sustaining the South African automotive industry (AIEC, 2014:4).

Governments play an important role in stimulating economies and the South African government is no exception to this through active participation in trade and industrial policy initiatives. One way for governments to advance trade, and specifically exports, is through trade agreements, which positively benefit trade among member countries by lowering trade tariffs as well as non-tariff barriers (Hayakawa, Ito \& Kimura, 2015:1). The removal of trade barriers through trade arrangements, such as the African Growth and Opportunity Act (AGOA) and regional integration on the African continent, promise increased opportunities between member countries (Hayakawa, Ito \& Kimura, 2015:1).

The AGOA is a non-reciprocal agreement between the United States of America (USA) and 39 developing subSaharan African (SSA) countries, including South Africa (Williams, 2014:215; AIEC, 2016:35). The primary goal of AGOA is to expand trade with Africa by capitalizing on vast and diverse opportunities and incorporating the continent into the world economy. Angelo and Davies (2015:171) go as far as to state that the AGOA has been "the cornerstone of USA-Africa trade policy". South Africa is viewed as the most active African country participating under the AGOA (Williams, 2014:204).

This paper reports on research with regard to the automotive trade between South Africa and the USA under the AGOA between 2001, when the AGOA was implemented, and 2015. It is suggested that more research regarding the South African automotive industry is required regarding the industry's competitiveness (Ambe, 2014:278) and how the industry can move towards higher internationalization (Fish, Adendorf \& Jonker, 2015:128), especially through the removal of trade barriers (Hayakawa, Ito \& Kimura, 2015:1). Regarding the latter, the potential opportunities of mutual benefit for the South African and the USA automotive industries relating to regional integration in sub-Sahara Africa could be a specific focus area.

This paper envisages addressing the following research question: What was the impact of the AGOA on automotive exports from South Africa to the USA from 2001 to 2015 ?

Following, the rationale for the study is presented after which the methodology and a literature review on the global and South African automotive industry are presented. The South African automotive export performance under the AGOA is presented and in conclusion, possible recommendations and suggestions for the future of the AGOA are also elaborated on.

\section{Rationale for the Study}

Although the South African automotive industry is defined as a crucial role player in terms of economic value and job creation, the industry is inundated with various competitive challenges in the global arena (Komarasamy \& Hoque, 2015:975). The research predicament addressed through this paper is that the South African automotive industry is faced by the reality of global overcapacity and therefore markets are saturated, which has negative implications for exports. The South African automotive industry is an export-oriented industry and therefore the challenge is how to grow exports with the vision to double vehicle production to one million units per annum by the year 2020 under the Automotive Production Development Programme (APDP). The APDP is the automotive policy regime in South Africa that was implemented on 1 January 2013 with its focus on high volume vehicle production and on increasing the local value addition. The ultimate goal is to grow the industry's manufacturing output as well as its export competitiveness (AIEC, 2014:15). The global recession since 2008 impacted negatively on the South 
African economy as well as its automotive market and it is in South Africa's best interest to stimulate growth through the export of manufactured goods (Fish, Adendorf \& Jonker, 2015:128-129) and increase global price competitiveness (Naude, 2013:408; Komarasamy \& Hoque, 2015:996).

In the light of this, the researchers allude to the fact that more research should be undertaken regarding the removal of trade barriers (Hayakawa, Ito \& Kimura, 2015:1) and competitiveness improvement of the South African automotive industry through effective internationalization of role players (Ambe, 2014:278; Fish, Adendorf \& Jonker, 2015:128).

Further to this, exports realize economies of scale and literature widely states that an increased competitive global environment requires increased exports in order to be sustainable as local markets are saturated (Fish, Adendorf \& Jonker, 2015:128). Government interventions, such as the removal of trade barriers through free trade area regional integration on the African continent, as well as the extension of unilateral trade arrangements, such as the African Growth and Opportunity Act (AGOA), might pose pioneering opportunities for the South African automotive industry.

The aim of this paper is to investigate the impact of the AGOA on South Africa's automotive exports to the USA over the past 15 years and to investigate how to further stimulate exports through regional integration opportunities in sub-Saharan Africa for both South Africa and the USA. The research question addressed is: What was the impact of the AGOA on automotive exports from South Africa to the USA from 2001 to 2015? As the AGOA was introduced in 2001, 2000 will be utilized as the base year for comparative reasons. The paper further proposes additional recommendations with regard to exports under the AGOA.

\section{METHODOLOGY}

This paper reports on research on South African automotive exports to the USA under the AGOA from 2001 to 2015. The quantitative trade data (secondary data) was based on the official detailed South African Revenue Service's (SARS) trade data for all automotive components and vehicles qualifying under the APDP. The average annual exchange rate was obtained from the South African Reserve Bank (www.resbank.co.za). The official trade data represents nominal free on board (FOB) values. The latest year's data (2015) was obtained for analysis of the export data under the AGOA regarding vehicles and component categories. The Automotive Industry Export Council (AIEC) is the official source and custodian of trade statistics of the South African automotive industry and the authors of this paper are extensively involved with the refinement of statistics for the AIEC and official approval was obtained to publish the data.

\section{LITERATURE REVIEW}

\section{Globalization}

Globalization opened up significant opportunities to larger markets internationally by allowing for cheaper factors of manufacturing (Fish, Adendorf \& Jonker, 2015:128). However, globalization also poses various challenges for certain industries and countries. Globally, supply chains compete against supply chains, not only on end products, and the entire industry therefore benefits when vehicles are exported. As an example, for a small open economy such as South Africa, it is becoming increasingly important to compete globally on a sustainable basis (Fish, Adendorf \& Jonker, 2015:128). It is important that trade strategies and agreements should be embraced for optimized benefits. One way that will enable South Africa to compete more equally is through regional trade agreements. Regional trade agreements positively benefit trade among member countries by lowering trade tariffs as well as non-tariff barriers (Hayakawa, Ito \& Kimura, 2015:1). An industry that benefits significantly from trade arrangements is the automotive industry.

\section{South African Automotive Industry}

The global automotive industry is widely recognized as the largest economic and socioeconomic contributor and therefore plays a crucial role in the global economy (Bronkhorst, Steyn \& Stiglingh, 2013:1282; Ambe, 2014: 638). Global vehicle production in 2015 rose by $1.1 \%$ to reach a record of 90,88 million vehicles - up from the 89,78 
million units produced in 2014 (AIEC, 2016:18). Globally, vehicle sales increased by $2.0 \%$ to 89,78 million vehicles during 2015 compared to the 87,92 million vehicles sold in 2014, which means that the global supply of vehicles exceeded demand by 1,1 million vehicles in 2015 (AIEC, 2016:16).

The South African automotive industry performs favorably with peer industries in emerging markets (Naude, 2013:407) and is inclusive of a comprehensive supply chain on different tiered levels (Ambe, 2014: 638; Tolmay \& Badenhorst-Weiss, 2015:2). The global automotive industry is intensely competitive and is characterized by world class management philosophies such as continuous improvement (CI), total quality management (TQM) and just-intime (JIT) supply chains (Naude, 2013:407).

Seven original equipment manufacturers (OEMs) are represented in South Africa, namely BMW, Ford, General Motors, Mercedes-Benz, Toyota, Nissan and Volkswagen, as well as 15 truck and bus companies, serviced by about 500 automotive component suppliers (Ambe, 2014: 638; AIEC, 2016:7). The industry in South Africa has one of the most competitive trading environments in the world and in 2015, offered no fewer than 55 brands and 2872 model derivative choices in the passenger car segment for consumers (AIEC, 2016:9). This affords consumers the largest selection to market-size ratio globally (AIEC, 2016:10).

South African vehicle production increased to a record 615658 vehicles in 2015, up from the 566131 units produced in 2014, resulting in a year-on-year gain of 49527 vehicles or 8.7\% (AIEC, 2016:18). The country subsequently improved its global ranking to 21 st (24th in 2014) in the world with a market share of $0.68 \%$ of the 90,88 million vehicles produced in 2015 (AIEC, 2016:18). A substantial number of vehicles manufactured in South Africa is earmarked for the export market with $67.0 \%$ of the 341025 passenger cars, $42.3 \%$ of the 242974 light commercial vehicles and 3.6\% of the 31659 of the medium and heavy commercial vehicles exported in 2015 (AIEC, 2016:10).

The increasingly integrated South African automotive industry is now playing in the international league. South Africa manufactures vehicles according to international standards, meaning that a vehicle manufactured in the country is identical to a vehicle manufactured in the USA or Europe. The following right and left hand drive passenger car and light commercial vehicle models were manufactured in South Africa in 2015 (AIEC, 2016:12)(table 1).

Table 1. Passenger cars and light commercial vehicles manufactured in 2015 (Adapted from AIEC, 2016:11)

\begin{tabular}{l|l}
\hline \multicolumn{2}{l}{ Passenger car models manufactured in South Africa in 2015} \\
\hline BMW & 3-Series 4-door \\
\hline General Motors & Chevrolet Spark \\
\hline Mercedes-Benz & C-Class 4-door \\
\hline Toyota & Corolla 4-door new and preceding series (designated Quest) and Fortuner \\
\hline Volkswagen & Polo new and previous series (designated Vivo) \\
\hline Light commercial vehicle models manufactured during 2015 in South Africa \\
\hline Ford & Ranger \\
\hline General Motors & Chevrolet Utility and Isuzu KB \\
\hline Nissan & NP200, NP300 Hardbody \\
\hline Toyota & Hilux and Quantum \\
\hline
\end{tabular}

The significance of the South African automotive sector is based on its substantial export earnings and contribution towards employment and GDP. The South African government acknowledges the importance of the automotive sector and is committed to enhancing, developing and growing the industry through economic initiatives (AIEC, 2014:4).

\section{Government Support}

Governments are playing crucial and proactive roles in promoting global economic trade strategies, and various studies support the importance of government's role in stimulating the macroeconomic environment (Fish, Adendorf 
\& Jonker, 2015:132). It is also the norm globally for governments to offer both financial and non-financial support to their automotive industries, with most countries offering a range of support measures to vehicle manufacturers. Governments actively attempt to attract automotive investments via policy and support measures because of the huge investment required to set up a plant, and in recognizing the benefits towards the country's economy with respect to fiscal contribution, employment creation, the transfer of technology and the positive multiplier effect on the broader economy (AIEC, 2016:16). The South African government is testimony to this and is also actively involved through policies in promoting growth opportunities for economic role players. The support by the South African government includes tariff protection, fiscal rebate mechanisms, non-taxable cash grants and international trade promotion activities (AIEC, 2016:8, 21-22).

The South African government also aims to constantly refine regional development and economic integration through industrialization and trade, and increasing manufacturing competencies are promoted with special emphasis on exports (AIEC, 2016:14). The drive from the South African government to increase opportunities for vehicles manufactured within the country is an important beneficiary factor for the industry (Lamprecht, Rudansky-Kloppers \& Strydom, 2011:55). The South African automotive industry would not be able to actively compete on a par with global peers if it was not for the proactive South African government support (Bronkhorst, Steyn \& Stiglingh, 2013:1282). Lamprecht et al. (2011:72) agree that intelligently designed automotive policies actively enhance prosperity for developing countries of which numerous benefits exist.

The partnership between government and the automotive sector in South Africa has a long and productive history. Certainty and stability in the official policy regime, over the past 20 years, have contributed to a number of noteworthy achievements by the vehicle manufacturing and associated industries. These include higher levels of vehicle production and vehicle exports, massive investments by multi-national automotive companies in manufacturing facilities in South Africa, significant model rationalization, employment stability, and an increasingly positive contribution by the industry to South Africa's balance of payments (AIEC, 2016:21). It is well recognized that the largest contribution towards the South African automotive industry was the introduction of government support programmes such as the Motor Industry Development Programme (MIDP) and the Automotive Production Development Programme (APDP).

The Motor Industry Development Programme (MIDP), implemented in 1995, and its successor, the Automotive Production Development Programme (APDP), implemented in 2013, represent some of the most innovative and successful programmes to retain a domestic vehicle and component manufacturing industry, which has continued to contribute positively to the South African economy and society. The APDP's vision is to double the country's vehicle production by 2020 to one million vehicles per annum. This means that the South African automotive industry's global vehicle production market share would increase by more than 1\% (AIEC, 2016:19). The anticipated higher market share increase should enhance additional investment interest and promises to realize increased export opportunities. The South African automotive sector relies on economies of scale through increased global competitiveness and exports are therefore crucial to its success (AIEC, 2015:16). Furthermore, the extension of the AGOA to 2025 and regional integration on the African continent promise to advance the industry sufficiently to be able to realize larger export numbers (AIEC, 2016:35).

\section{Regional Integration}

Economic integration is facilitated by the regulations and rules stipulated by the World Trade Organization (WTO), International Monetary Fund (IMF), as well as the World Bank (Aregbeshola, Oosthuizen, Aregbeshola, Luiz, Ojah, Palmer \& Venter, 2012:57). These three organizations establish rules and regulations and also adjudicate global trade-related disputes, and promote global trade and investment through treaties with the aim of fair trade (Aregbeshola et al. 2012:57). Regional economic integration comprises membership countries located in the same geographical area where trade barriers are largely removed. A free trade area is a regional economic grouping of countries with no or minimal tariff and non-tariff barriers, while a common market entails a customs union through member countries to liberalize movement of regional production that might include resources such as capital. South Africa forms part of the Southern African Development Community (SADC), comprising 15 sub-Saharan African countries, which allows market access to approximately 300 million people within the region and an estimated regional GDP of US\$600 billion (AIEC, 2016:42). The country also forms part of the five-country Southern African 
Customs Union (SACU). Finally, an economic union, as part of economic integration, aims to harmonize the fundamental economic policies of its member countries such as fiscal and monetary policies (Aregbeshola et al. 2012:57-58). Regional integration could enhance opportunities for the automotive industry while the industry could also be a driver of regional integration by placing pressure on governments to increase market access and improve cross border infrastructure.

\section{Generalized System of Preference}

Even before the AGOA was implemented, South Africa has enjoyed the benefits of the USA's Generalized System of Preferences (GSP) since 1 January 1976, which provides duty-free status to specified goods. South Africa falls under the 120 developing countries that benefit from GSP (Williams, 2014:203). The African Growth and Opportunity Act (AGOA), an extension of the GSP, has allowed duty-free access into the USA for more products and has significantly enhanced trade with the USA since 2001. The GSP covered 4800 products and this was later expanded to an additional 1800 items through the AGOA (Williams, 2014:207). A total of 98\% of products traded with the USA at present qualify for duty-free access (AIEC, 2016:35; Lamprecht, 2009:53). As a result, various automotive components and, importantly, vehicles qualify for quota-free and duty-free access into the USA. The duty rates into the USA vary from 2.5\% for passenger cars to 25\% for commercial vehicles (Lamprecht, 2009:299; AIEC, 2016:35). The removal of tariffs enhances the potential for South Africa to compete against the same products from other countries entering the USA but not enjoying similar tariff benefits.

\section{The African Growth and Opportunity Act}

The AGOA, built on the GSP, provides for more duty-free products than the GSP itself (Christie \& Breinlich, 2015:4). The effective period of the duty-free AGOA provision was initially from 1 January 2001 until 30 September 2008, and was thereafter extended until 30 September 2015 (Lamprecht, 2009:299).

The AGOA grants 39 sub-Saharan African (SSA) duty-free importations of specified goods into the United States of America (www.thedti.gov.za). The AGOA aims to encourage export growth and economic development in SSA and improve the USA's relations with the region (Williams, 2014:203). The AGOA was recently renewed for another decade until 30 September 2025 (AIEC, 2016:35; Pigman, 2016:1). South Africa, however, faced an out-of-cycle review that assessed the country's continued eligibility under Section 104 (a) of the Act, which deals with a beneficiary's progress towards being a market-based economy with open, rules-based trading and minimal government interference. The out-of-cycle review, owed primarily to concerns over restrictions on American poultry exports as well as health and safety restrictions on other meat products, has subsequently been concluded. South Africa's AGOA eligibility, along with the eligibility of all other beneficiaries, will remain subject to a yearly review over the 10-year extension period for the AGOA to mid-2025 (AIEC, 2015:35). The uncertainty of an annual review could potentially result in negative consequences for South African-based OEMs considering exports to the USA, for expanded passenger car and light commercial vehicle exports by existing exporters, or for future new generation model exports from South Africa to the USA. Reduced vehicle exports would also impact negatively on the entire supply chain and employment in the domestic automotive industry.

South Africa is the most economically advanced country of the AGOA members and accounts for the majority of imports into the USA, with manufactured vehicles being of major importance (Williams, 2014:204). Automotive trade between South Africa and the USA has increased substantially since the introduction of the AGOA, as US consumers benefit greatly from the reduced or absent import duties (AIEC, 2015:35). American automotive companies have a long standing history with South Africa. In 1924 Ford was the first OEM that established a subsidiary company in South Africa to assemble vehicles, followed by General Motors in 1926 (Tolmay, 2012:23). Added to the OEMs, top American automotive component suppliers are well-represented in South Africa, including Lear, Johnson Controls, Delphi, TRW Automotive, Federal Mogul, Tenneco, ArvinMeritor and Visteon, among others (AIEC, 2014:28).

However, the AGOA requires that trade is bound to rules of origin (RoO) (Pigman, 2016:2). Countries exporting products under the AGOA must meet certain requirements and rules of origin (RoO) to qualify for the duty-free privilege. Firstly, the duty-free products only allow for the product to be imported directly from the country of 
origin, and secondly at least $35 \%$ of the value of the product must be manufactured (in the case of vehicles) in the country of origin, which might include raw materials from other AGOA beneficiaries (Williams, 2014:207).

Thus, the AGOA provides three benefits for the exporting countries residing in sub-Saharan Africa, namely: the extension of duty-free treatment under the GSP programme, the elimination of trade limitations of the GSP programme, and the expansion of product coverage of the GSP programme.

The findings with regard to South African and USA automotive trade under the AGOA will now be discussed.

Findings Regarding Trade Between the USA and South Africa (2001 - 2015)

Most observers agree that the AGOA is successful in increasing more diversified exports to the USA, and South Africa has accounted for the bulk of general imports into the USA under the AGOA since 2001 (Williams, 2014:204). The AGOA combined trade between the USA and all members in all industries amounted to US\$36 billion in 2015, from US\$28 billion in 2000; however, 2013 reflected total combined trade as high as US\$61 billion (Pigman, 2016:3).

Automotive export figures between South Africa and the USA also revealed a substantial increase. From 2000 to 2001, when the AGOA was implemented, South African automotive exporters capitalized on the unilateral trade arrangement and automotive exports to the USA increased by a significant $296.4 \%$ in rand value terms from R1 187,00 million to R4 705,20 million (AIEC, 2007:63). From 2001 to 2015, the total trade between South Africa and the USA under the AGOA increased from R7 080,70 million to R32 782,40 million (table 2), representing an accrued increase of $362.9 \%$ in rand value terms and $211,2 \%$ in USA dollar terms. The USA became South Africa's top destination for its light vehicle exports since 2008. The USA was the only export destination for the left-hand drive Mercedes-Benz C-Class model as well as the top destination for the BMW 3-series model since 2008 (AIEC, 2014:29). South Africa's exports to the USA increased from R 4 705,20 million in 2001 to R20 946,90 million in 2015 under the AGOA, which represents an $345.1 \%$ accrued increase in rand value terms, while the USA's exports to South Africa increased from R2 375,10 million to R11 835,50 million amounting to a massive 398,3\% accrued increase in rand value terms over the same period (table 2).

Table 2. Automotive trade between South Africa and USA (2000 - 2015) (in nominal South African rand value terms) ${ }^{2}$ Adapted from AIEC $(2007: 63 ; 2016: 27)$

\begin{tabular}{|c|c|c|c|c|}
\hline & Year & $\begin{array}{c}\text { SA exports to USA } \\
\text { R Million }\end{array}$ & $\begin{array}{c}\text { USA exports to SA } \\
\text { R Million }\end{array}$ & $\begin{array}{l}\text { Total trade } \\
\text { R Million }\end{array}$ \\
\hline Base Year & 2000 & $\mathrm{R} 1187,00$ & R1 761,50 & R2 948,50 \\
\hline \multirow{15}{*}{ African Growth and Opportunity Act } & 2001 & R4 705,20 & R2 375,10 & R7 080,30 \\
\hline & 2002 & R6 292,50 & R2 936,00 & R9 228,50 \\
\hline & 2003 & R5 384,50 & R2 991,40 & R8 375,90 \\
\hline & 2004 & R4 181,60 & R2 968,70 & R7 150,30 \\
\hline & 2005 & R3 206,50 & R3 238,80 & R6 445,30 \\
\hline & 2006 & R5 769,70 & R3 916,50 & R9 686,20 \\
\hline & 2007 & R6 903,00 & R5 407,00 & R12 310,00 \\
\hline & 2008 & R17 871,10 & R6 354,50 & $\mathrm{R} 24225,60$ \\
\hline & 2009 & R15 000,80 & R4 076,40 & R19 077,20 \\
\hline & 2010 & R15 718,20 & R5 253,30 & R20 971,50 \\
\hline & 2011 & R19 099,70 & R8 285,50 & $\mathrm{R} 27385,20$ \\
\hline & 2012 & $\mathrm{R} 18623,10$ & R9 616,10 & R28 239,20 \\
\hline & 2013 & R19 138,70 & R10 020,00 & R29 158,70 \\
\hline & 2014 & R17 145,00 & R11 817,20 & R28 962,20 \\
\hline & 2015 & R20 946,90 & R11 835,50 & R32 782,40 \\
\hline
\end{tabular}

\footnotetext{
${ }^{2}$ The annual currency conversion (South African rand to US\$1) according to the South African Reserve Bank (www.resbank.co.za): 2000 (R6,94 to 1US\$), 2001 (R8,57 to 1US\$), 2002 (R10,56 to 1US\$), 2003 (R7,51 to 1US\$), 2004 (6,44 to 1US\$), 2005 (R6,36 to 1 US\$), 2006 (R6,76 to 1US\$), 2007 (R7,05 to 1US\$), 2008 (R8,24 to 1US\$), 2009 (R8,41 to 1US\$), 2010 (R7,31 to 1US\$), 2011 (R7,25 to 1US\$), 2012 (R8,21 to 1US\$), 2013 (R9,64 to 1US\$), 2014 (R10,84 to 1US\$), 2015 (R12,75 to 1US\$).

Copyright by author(s); $\underline{\text { CC-BY }}$ 
Figure 1 reveals that automotive trade between South Africa and the USA increased substantially under the AGOA from 2001 to 2015, with USA automotive exports to South Africa proportionally increasing more than South African automotive exports to the USA under the AGOA.

Figure 1. AGOA automotive trade between South Africa and USA (2000 - 2015) (South African rand value)

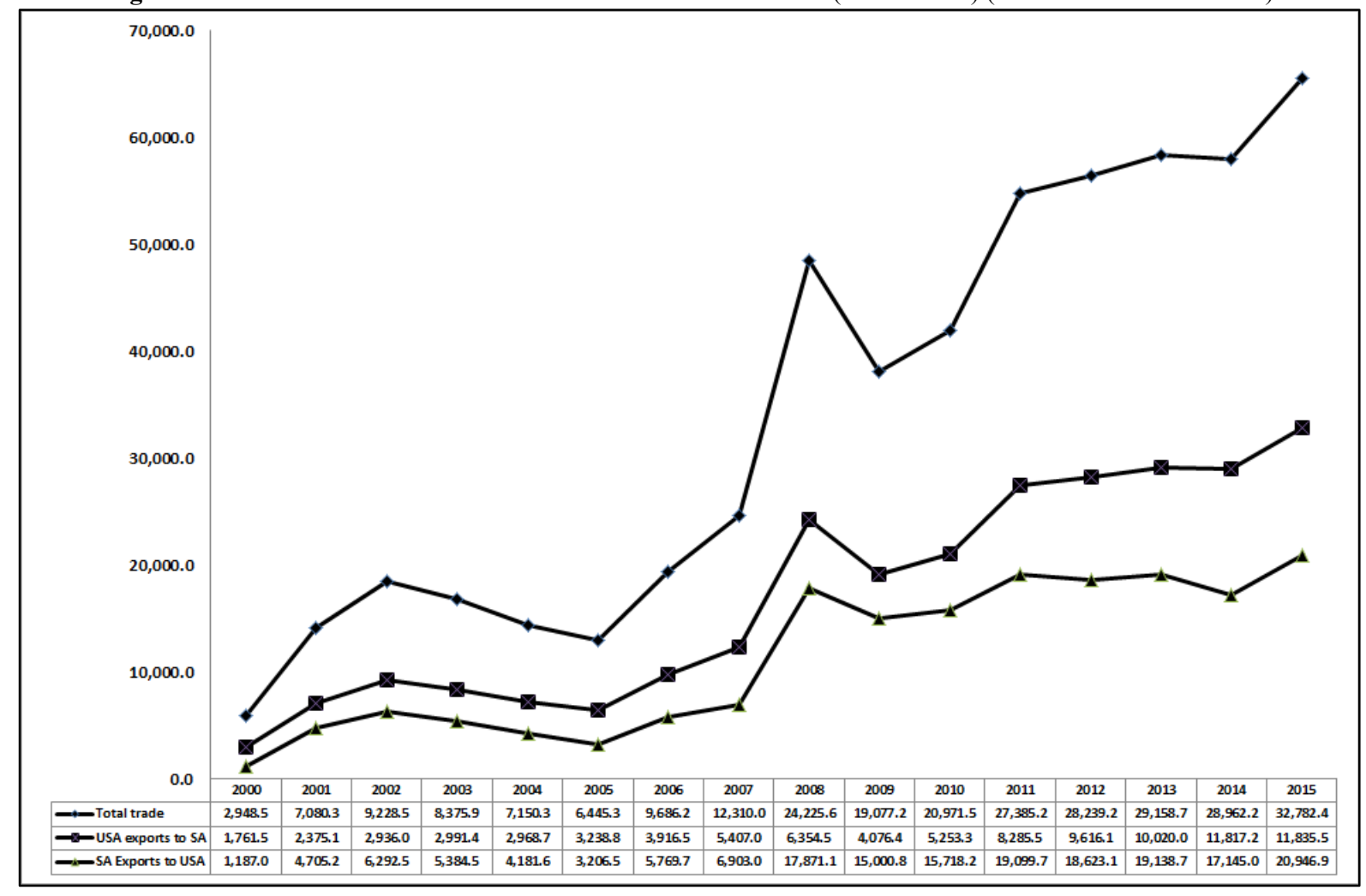

During 2015 the major automotive export products from South Africa to the USA comprised mainly light vehicles, catalytic converters, engine parts, radiators and parts, silencers and exhausts, and tires. The left-hand drive BMW 3series as well as the new generation Mercedes-Benz C-Class models comprised the vehicle model exports to the USA in 2015 (AIEC, 2016:35). The major automotive products exported from the USA into South Africa comprised mainly light vehicles, original equipment components, engine parts, engines, transmission shafts and cranks, tires, gauges and instrument parts, automotive tooling, axles, and catalytic converters (table 3). 
Table 3. South Africa and USA automotive trade $2015^{3}$ (Adapted from AIEC, 2016:76)

\begin{tabular}{l|c|l|r}
\hline \multicolumn{1}{c}{ Main products } & $\begin{array}{c}\text { R32 782,40 million } \\
\text { Exports from SA } \\
\text { R20 946,90 million }\end{array}$ & \multicolumn{1}{c}{ Main products } & $\begin{array}{c}\text { Imports into SA } \\
\text { R11 835,50 million }\end{array}$ \\
\hline Light vehicles & $\mathrm{R} 14$ 424,30 & Light vehicles & $\mathrm{R} 4744,00$ \\
\hline Catalytic converters & $\mathrm{R} 4063,00$ & Original equipment components & $\mathrm{R} 1835,00$ \\
\hline Engine parts & $\mathrm{R} 923,00$ & Engine parts & $\mathrm{R} 765,10$ \\
\hline Radiators / parts & $\mathrm{R} 228,00$ & Engines & $\mathrm{R} 512,00$ \\
\hline Silencers / exhausts & 177,50 & Transmission shafts / cranks & $\mathrm{R} 419,00$ \\
\hline Tires & $\mathrm{R} 133,50$ & Tires & $\mathrm{R} 316,50$ \\
\hline Automotive tooling & $\mathrm{R} 117,00$ & Gauges / instruments / parts & $\mathrm{R} 283,00$ \\
\hline Axles & $\mathrm{R} 81,00$ & Automotive tooling & $\mathrm{R} 266,00$ \\
\hline Gear boxes & $\mathrm{R} 59,40$ & Axles & $\mathrm{R} 111,00$ \\
\hline Shock absorbers / suspension parts & $\mathrm{R} 58,00$ & Catalytic converters & $\mathrm{R} 101,30$ \\
\hline Other & $\mathrm{R} 684,00$ & Other & $\mathrm{R} 2484,00$ \\
\hline
\end{tabular}

Various observations were made by the researchers such as the increased opportunities of mutual benefit in respect of the automotive industry under the AGOA, as well as the substantial two-way trade increase in automotive products between South Africa and the USA in both volume and value terms. The AGOA benefitted South Africa as well as the USA where the new South African Ford engine manufacturing plant resulted in an additional 800 jobs for a Kansas Ford plant (http://www.iol.co.za). In general, the scope and composition of products traded between South Africa and the USA has broadened.

\section{Discussion}

The American global automotive corporations have fostered solid business links between South African and international stakeholders such as Ford, General Motors and multinational corporations (MNCs) on the component supply side. As OEMs source their components globally at world-best prices, subject to quality and delivery standards, USA companies benefited greatly from the duty-free access to South African manufactured products under the AGOA. In return, the increased South African component and vehicle exports to the USA resulted in the growth of the South African automotive industry, thereby contributing to increased employment, higher volumes relating to scale economy benefits, and business retention in general. The improved employment opportunities also presented themselves with the demand for reciprocal technical expertise and technology growth as well as increased logistics, in particular, automotive shipping links between the two countries.

The elimination of tariffs improves a country's potential to compete against peers who do not enjoy the same benefits for the products exported to the relevant country. South Africa is capitalizing on vehicle market access under the AGOA into the USA as one of only a few countries on the continent able to do so. Trade in automotive products between South Africa and the USA under the AGOA has expanded substantially since 2001, resulting in American consumers also being able to reap the benefits of the reduced import duties on vehicles and automotive components. The import of original equipment components, vehicles and replacement parts into South Africa from the USA has also grown considerably. The AGOA and its extension beyond 2015 is aligned with the continent's regional-integration ambitions, thereby enabling USA companies to benefit from African market expansion (AIEC, 2015:36).

South Africa, as part of Africa and with its wealth of experience and built-for-Africa vehicles, is ideally positioned to capitalise from the increased demand for vehicles, assembly kits and automotive components on the continent. South Africa's proximity compared to other emerging markets and its understanding of business conditions and practices in other African countries, places it in the favorable position of being the ideal partner for assistance in establishing a vehicle assembly operation, in return for some kind of preferential treatment while the component sector is being developed there. The wealth of management experience in the country and understanding of the

${ }^{3}$ The annual average currency conversion for 2015 was R12,75 (South African rand) to US\$1 according to the South African Reserve Bank. (www.resbank.co.za).

Copyright by author(s); $\underline{\mathrm{CC}-\mathrm{BY}}$ 
issues that an African production site entails could ensure the optimizing of operations and costs in both countries (AIEC, 2016:35).

In addition, following the implementation of the Nigerian Automotive Industry Development Plan (NAIDP) in 2014, which resulted in an increase in import duties for passenger cars from $35 \%$ to $70 \%$, Ford and Nissan started vehicle assembly operations in the country in order to import up to twice as many completely built-up vehicles as they assemble in the country at the reduced import duty rate of 35\% for passenger cars and $20 \%$ for commercial vehicles (www.engineeringnews.co.za). This will be the first Ford production plant in Africa outside of South Africa.

\section{CONCLUSION AND RECOMMENDATIONS}

Globalization brought about a number of opportunities through extended markets, which is also true for the automotive industry. The South African automotive industry is no exception to this and benefitted greatly through globalization, but also experienced intensified pressure from increased competition. The South African automotive industry is faced with the challenge of how to expand market share through exports in a saturated global automotive market characterized by overcapacity.

As governments play an important role through their global trade policies, the South African government is also involved in promoting the automotive industry and encouraging access to new markets. Trade arrangements such as the AGOA enhance exports while also contributing to regional integration on the African continent. Through the preceding GSP to the extensions of the AGOA trade arrangement, the South African automotive industry established extensive automotive two-way trade with the USA.

The study reported on in this paper analyzed automotive export statistics between 2001, when the AGOA was implemented, and 2015. It aimed to address the question: What was the impact of the AGOA on automotive exports from South Africa to the USA from 2001 to 2015?

It was found that automotive vehicle and component exports increased substantially in nominal terms from 2000 to 2001, when the AGOA was implemented, as well as subsequently from 2001 to 2015 under the AGOA. Importantly, considerable two-way trade was realized for South Africa and the USA with the growth in automotive exports from the USA to South Africa being proportionally much higher than the growth in South African automotive exports to the USA under the AGOA. Not only did the AGOA substantially benefit South Africa, but it also provides the USA with niche access to the African region, which was previously untapped. The AGOA's win-win dispensation for both South Africa and the USA builds goodwill and results in regional development and positive integration momentum. The ten-year extension of the AGOA trade arrangement up to 2025 promises to strengthen further automotive trade relations between South Africa and the USA, resulting in increased employment creation, industrial growth, and development in the southern African region in general. The extension could also provide a catalyst for the other five South African OEMs to pursue export opportunities for passenger cars and light commercial vehicle exports to the USA market.

In order to grow its automotive export business, it is important for the South African automotive industry to forge close links with automotive programmes currently under development in Africa. Strong regional industrial economies would enhance manufacturing opportunities in the relevant countries, providing a platform for intraregional trade and economic partnerships of mutual benefit. It is likely that an Africa automotive industry-wide initiative could emerge in the near future. Such an initiative will make it possible for African countries to supply each other with original equipment components, as well as aftermarket parts and vehicles, while also exporting these to other regions. This should undoubtedly be Africa's ambition. If the AGOA trade arrangement should expire or exclude South Africa, it will substantially disrupt trade between the two regions. As a result, intra-African trade will decline and regional integration will reduce, ultimately resulting in the diminishing of AGOA's value to Africa. 
This paper makes a valuable contribution to the insight of the AGOA trade arrangement between South African and the USA and its potential impact on stimulating further regional automotive opportunities in sub-Saharan Africa for both countries. Further research is encouraged and may provide insight into the AGOA automotive trade over a longer period up to 2025. Researchers are also invited to investigate the effect and potential opportunities of regional economic integration relating to the Tripartite Free Trade Area (TFTA) comprising the East African Community (EAC), the Common Market for Eastern and Southern Africa (COMESA) and the Southern African Development Community (SADC) on both the South African and USA automotive industries. The TFTA represents an important landmark in the implementation of the development integration agenda in Africa aimed at the promotion of market integration, based on infrastructure and industrial development.

\section{AUTHOR BIOGRAPHIES}

Dr. N. Lamprecht is Executive Manager of the National Association of Automobile Manufacturers of South Africa (NAAMSA) and Director of the Automotive Industry Export Council (AIEC). He is also contracted at the University of South Africa (Unisa) as an external promoter for masters and doctoral students in the automotive field at the Department of Business Management. He has 27 years extensive knowledge of the national and international automotive industry and since 2005 he has established the AIEC as the official source of South African automotive trade data as contained in his annual AIEC Automotive Export Manual publications.

Dr. A. S. Tolmay is a senior lecturer at the University of South Africa within the Department of Production and Operations Management. Prior to joining the academia in 2014, Dr Tolmay worked for various companies in the corporate industry for 24 years. Dr Tolmay is extensively involved with research regarding the global and South African automotive industry and related supply chain activities.

\section{AUTHOR STATEMENT}

Neither of the authors received any financial assistance for the compilation of this paper. No conflict of interest is applicable.

\section{SIGNIFICANCE OF WORK}

This paper makes a valuable contribution through insight to the African Growth and Opportunity Act (AGOA) trade arrangement between South Africa and the United States of America (USA) and its potential impact on stimulating further regional automotive opportunities in sub-Saharan Africa for both countries. An analysis was done depicting the mutual automotive trade opportunities between South Africa and the USA from 2001 to 2015. The impact of the AGOA between South Africa and the USA is discussed and recommendations are made.

\section{REFERENCES}

AIEC. (2016). Automotive Export Manual 2016 - South Africa. Pretoria: Zest (Pty) Ltd. ISBN978-0-620-70287-4. AIEC. (2015). Automotive Export Manual 2015 - South Africa. Pretoria: Zest (Pty) Ltd. ISBN978-0-620-65335-0. AIEC. (2014). Automotive Export Manual 2014 - South Africa. Pretoria: Zest (Pty) Ltd. ISBN978-0-620-59886-6. AIEC. (2007). Automotive Export Manual 2007 - South Africa. Pretoria: Zest (Pty) Ltd.

Ambe, I. M. (2014). Alignment Of Supply Chain Strategies And Practices Of Locally Made Vehicles In South Africa. The International Business \& Economics Research Journal (Online), 13(3), 637.

Angelo, A. M., \& Davies, T. A. (2015). “American business can assist [African] hands:” the Kennedy administration, US corporations, and the cold war struggle for Africa. The Sixties, 8(2), 156-178.

Aregbeshola, A., Oosthuizen, T., Luiz, J., Ojah, K., Palmer, P., \& Venter, P. (2011). Global Business, Environments and Strategies. Fourth Edition. Pretoria: USA Oxford University Press. ISBN 9780195997705.

Barnes, J., \& Black, A. (2013, May). The Motor Industry Development Programme 1995-2012: What have we learned?. In International Conference on Manufacturing-led Growth for Employment and Equality. 1-38.

Barnes, J. (2013). Capital structure of the South African automotive industry: Historical perspectives and development implications. Transformation: Critical Perspectives on Southern Africa, 81(1), 236-259.

Bronkhorst, E., Steyn, J., \& Stiglingh, M. (2013). The Automotive Production and Development Programme: an analysis of the opinions of South African stakeholders. Journal of Applied Business Research, 29(5), 1281-1300.

Copyright by author(s); $\underline{\text { CC-BY }}$ 
Christie, D., \& Breinlich, H. (2015). "US and EU trade preferences towards the developing countries. A comparison." Economics of the EU. 1-15.

Cook, N. P., \& Jones, J. C. (2015). The African Growth and Opportunity Act (AGOA) and export diversification. The Journal of International Trade \& Economic Development, 24(7), 947-967.

Engineering News. 2015. Nemeth to tackle growth obstacles through new African auto body. http://www.engineeringnews.co.za/article/whitfield-nemeth-to-tackle-growth-obstacles-through-new-african-autobody-2016-04-21. Irma Venter. Published on 12 August 2015 and 25 September 2015. Accessed on 7 June 2016.

Fish, C., Adendorff, C., \& Jonker, K. (2014). An investigation into factors impacting on exports from South Africa to the Southern African Development Community (SADC). African Sociological Review/Revue Africaine de Sociologie, $18(1), 127-148$

Gerstenfeld, A., \& Njoroge, R. (2003). African Growth and Opportunity Act (AGOA). The International Journal of Business Disciplines, 14(2),1-19.

Hayakawa, K., Ito, T., \& Kimura, F. (2016). Trade Creation Effects of Regional Trade Agreements: Tariff Reduction versus Nontariff Barrier Removal. Review of Development Economics, 20(1), 317-326.

IOL. 2016. Zuma meets US congressmen to seek SA's inclusion in fresh Agoa. http://www.iol.co.za/business/zuma-meets-uscongressmen-to-seek-sas-inclusion-in-fresh-agoa-1731045). Accessed on 1 June 2016.

Komarasamy, J., \& Hoque, M. E. (2015). Factors affecting the sustainability of the South African automotive component industry. Journal of Contemporary Management, 12, 974-998.

Lamprecht, N., Rudansky-Kloppers, S., \& Strydom, J. W. (2011). South African automotive policy intervention (1924-2008): the case of an intelligently designed automotive support structure. Journal of Contemporary Management, 8, 54-75.

Lamprecht, N. (2009). The impact of the Motor Industry Development Programme (MIDP) on the export strategies of the South African light motor vehicle manufacturers (1995-2008) (Doctoral dissertation, University of South Africa).

Mund, K., Pieterse, K., \& Cameron, S. (2015). Lean product engineering in the South African automotive industry. Journal of Manufacturing Technology Management, 26(5), 703-724.

Naude, M. J., \& Badenhorst-Weiss, J. A. (2011). Supply chain management problems at South African automotive component manufacturers. Southern African Business Review, 15(1), 71-99.

Naude, M. J. (2013). Supply chain challenges in the South African automotive sector: Do location, size and age matter?. South African Journal of Economic and Management Sciences, 16(4), 407-417.

OICA. 2016. Production statistics. http://www.oica.net/category/production-statistics/_Accessed on 19 May 2016.

Pigman, G. A. 2016. "AGOA-IV and the Trade Prospects of Sub-Saharan Africa". http://www.oecd-ilibrary.org. Accessed on 7 June 2016 from The Commonwealth, 127, 1-8. ISSN: 2071-8527.

Sies, M. C. (2014). Introduction: critical sustainability studies in sub-Saharan Africa. Africa Today, 61(1), vi-xviii.

South African Reserve Bank. Publications. Quarterly Reports. www.resbank.co.za. Accessed on 9 June 2016.

The DTI. Trade agreements. https://www.thedti.gov.za/trade_investment/ited_trade_agreement.jsp Accessed on 26 April 2016.

Tolmay, A. S., \& Badenhorst-Weiss, J. A. (2015). Supply chain relationships between first and second tier suppliers in South African automotive supply chains: A focus on trust. Journal of Transport and Supply Chain Management, 9(1), 1-8.

Tolmay, Aletta Sophia. 2012. "Developing a relationship value model (RVM) for the South African B2B automotive supply chain." (Doctorate dissertation, University of South Africa).

Williams, B. R. (2014). African growth and opportunity act (AGOA): Background and reauthorization. Current Politics and Economics of Africa, 7(3), 203-227. 